ТЕХНОЛОГІЯ ЗАСТОСУВАННЯ ДИДАКТИЧНОЇ ГРИ НА УРОКАХ МАТЕМАТИКИ В ПОЧАТКОВІЙ ШКОЛІ

\title{
THE TECHNOLOGY OF APPLICATION OF THE DIDACTIC GAME AT MATHEMATICS LESSONS AT PRIMARY SCHOOL
}

\begin{abstract}
у статті обірунтовано сутність $і$ зміст організації творчої, активної пізнавальної діяльності учнів у початковій школі. Представлено сучасні вимоги до прочесу навчання молодших школярів математики в контексті активізації їхньої пізнавальної діяльності. Визначено ефективність застосування методу дидактичної гри в навчанні молодших школярів на основі вивчення літературних джерел, узагальнення прогресивного педагогічного досвіду вчителів початкової школи. Обгрунтовано зміст та основні напрями роботи з використання дидактичних ігор в освітньому прочесі. Запропоновано технологію організації і проведення дидактичної гри на уроках математики в початковій школі. Показано, що застосування ігрового методу в навчанні учнів початкових класів сприяє розвиткові їхніх пізнавальних інтересів, фрормуванню в них високих моральних почуттів, становленню їх як особистостей.
\end{abstract}

Спостереження за навчальною діяльністю учнів, анкетування, бесіда з вчителями виявили вимоги, які висуваються до відбору дидактичних ігор, що використовуються в прочесі навчання молодших школярів.

Доведено доцільність застосування методу дидактичної гри в навчанні молодших школярів. Охарактеризовано активні методи викладання математики в початковій школі. Запропоновано правила для використання ігрових методів на уроках у початкових класах: ігрове завдання завжди має збігатися зі змістом навчального завдання; частка ігрового методу навчання повинна знижуватися відповідно до формування пізнавальних інтересів учнів; дидактична гра повинна мати чітко визначену дидактичну мету, яка повинна бути підпорядкована цілям кожного конкретного уроку і допомогти досягненню цих цілей; дидактична гра має відповідати віковим особливостям учнів; дидактична гра проводиться систематично й цілеспрямовано протягом навчального року. Виокремлено власні рекомендації щодо використання дидактичних ігор у навчанні математики молодших школярів.

Ключові слова: активна пізнавальна діяльність, методи активного навчання математики, дидактична гра.
The article substantiates the essence and content of the organization of creative, active cognitive activity of students in primary school. The modern requirements to the process of teaching junior students mathematics in the context of activating their cognitive activity are presented. The efficiency of application of the method of didactic game in teaching of junior schoolchildren on the basis of studying of literary sources, generalization of progressive pedagogical experience of primary school teachers is determined. The content and main directions of work on the use of didactic games in the educational process are substantiated. The technology of organizing and conducting a didactic game in mathematics lessons in primary school is proposed. It is shown that the application of the game method in the teaching of primary school students contributes to the development of their cognitive interests, the formation of their high moral feelings, their formation as individuals.

Observations of students' learning activities, questionnaires, conversations with teachers, revealed the requirements for the selection of didactic games used in the learning process of primary school children.

The expediency of applying the method of didactic game in teaching junior schoolchildren is proved. Active methods of teaching mathematics in primary school are characterized.

The rules for the use of game methods in lessons in primary school are proposed: the game task should always coincide with the content of the educational task; the share of the game method of teaching should decrease in accordance with the formation of cognitive interests of students, didactic game should have a clearly defined didactic purpose, which should be subordinated to the objectives of each lesson and help achieve these goals; didactic game should correspond to the age characteristics of students, didactic game is carried out systematically and purposefully during the school year. Our own recommendations for the use of didactic games in teaching mathematics to primary school children are highlighted.

Key words: active cognitive activities, methods of active mathematics teaching, didactic game, training of future primary school teachers.
Постановка проблеми в загальному вигляді. Сучасні умови підвищують вимоги до професійного рівня вчителя початкової школи, націлюють на активізацію пізнавальної діяльності учнів, фрормування особистості наділеної творчим мисленням. Проблема розвитку здібностей особистості, творчої уяви, інтуїтивного мислення, оригінальних способів дії, відходу від шаблонів, націлює фрахівців початкової освіти на фрормування ініціативної, самостійної, мобільної особистості. Проводяться пошуки активних методів та засобів розв'язання поставлених завдань удосконалення у сорері початкової освіти.
Аналіз останніх досліджень і публікацій. Психологічні і педагогічні дослідження, а також практика початкової школи доводять, що найбільш велике значення вактивізації пізнавальної діяльності учнів випадає на ігрову діяльність під час вивчення математики. Цей новий тип діяльності Л. Виготський характеризує як перехід до творчої діяльності, якщо мати на увазі той фракт, що у всіх видах діяльності молодшого школяра виникає можливість втілення задуму, можливість йти від думки до ситуації, а не від ситуації до мети. Уява молодшого школяра носить активний характер, у 
них розвивається здатність до творчої діяльності. Це підтверджується і тим, що дедалі більше уваги учні починають приділяти ідеї, задуму[8].

Різні аспекти теорії дидактичної гри розглядались у працях О. Леонтьєва, Д. Ельконіна, А. Усової, М. Яновської, Д. Менджерицької.

У процесі педагогічної роботи виявлено, що розвиток творчого мислення на уроках математики в початкових класах безпосередньо залежить від активації здібностей, пізнавального інтересу до навчання; науково-діяльнісного і нестандартного мислення. Основними умовами розвитку творчого мислення є: відповідна побудова навчального процесу 3 орієнтації на теоретичне мислення; використання методів проблемного навчання, забезпечення необхідної емоційної та доброзичливої атмосфери, активних способів розвитку самостійності учнів, їхньої франтазії, уяви; опора на зону найближчого розвитку учня, креативний підхід у навчанні.

Виділення не вирішених раніше частин загальної проблеми. Саме тому, зростає кількість вітчизняних та зарубіжних досліджень, що розкривають основи удосконалення, а також застосування сучасних методів організації активної взаємодії в умовах навчального закладу (Г. Коберник, О. Комар, І. Осадченко та ін.).

Метою статті $€$ аналіз сутності та змісту організації активної пізнавальної діяльності учнів у початковій школі,розвитку творчих здібностей учнів та виокремлення власних рекомендації щодо використанняметоду дидактичної гри у навчанні математики молодших школярів.

Виклад основного матеріалу. Глибокий і складний процес перетворення і засвоєння життєвих вражень відбувається в іграх. Творчий початок виявляється у задумі, виборі теми гри, малюнка, у способах здійснення задуманого, передачі відношення до зображуваного, свої думки і почуття. Завдання вчителя - розвивати творчі здібності учня, уяву, спонукувати його йти від думки до дії.

Дитяча творчість основана на наслідуванні, що служить важливим фрактором розвитку учнів, їхніх здібностей. Завдання вчителя - прищеплювати їм навички й уміння, без яких неможлива творча діяльність, виховувати в них самостійність, активність у застосуванні знань і умінь, фрормувати критичне мислення, цілеспрямованість.

Навчання відіграє велику роль у пізнавальній діяльності учня. Творчий початок сприяє процесу засвоєння навичок. Свідомість відіграє ведучу роль у творчій діяльності учня, де уява, спирається на досвід і знання. Здатність до аналізу, критичного відношення до якості своєї роботи, дають перспективу для подальшого розвитку і зміцнення творчих здібностей учнів.

У молодшому шкільному віці закладаються основи пізнавальної діяльності, що виявляються у розвитку здатності до задуму і його реалізації, в умінні комбінувати свої знання і уявлення через передачу своїх почуттів. Творча уява учня виявляється і розвивається у грі, конкретизуючись у цілеспрямованому ігровому задумі. У грі учні виявляють емоції, що у житті ще недоступні їм. І. Сєченов довів, що ігрові переживання залишають глибокий слід у свідомості учня. Учні реалізують свій задум за допомогою мови, жестів, міміки, уживаючи різні предмети, спорудження, будівлі [8].

Основний вид діяльності учнів початкової школи - гра, у процесі якої розвиваються духовні і фрізичні сили дитини; його увага, пам'ять, уява, дисциплінованість, спритність, своєрідний, властивий молодшому шкільному віку спосіб засвоєння суспільного досвіду. У грі фрормуються всі сторони особистості учня, відбуваються значні зміни в його психіці, що готують перехід до нової, більш високої стадії розвитку. Під цим ми розуміємо величезні виховні можливості гри, яку педагоги та психологи вважають ведучою діяльністю молодшого школяра [2].

Гра - самостійна діяльність, у якій учні вступають у спілкування з однолітками. Їх поєднує єдина мета, спільні зусилля до її досягнення, загальні інтереси і переживання. Гра - важливий засіб розумового виховання дитини. Знання, отримані в школі, знаходять у грі практичне застосування і розвиток.

У грі розумова активність дітей завжди зв'язана з роботою уяви; потрібно знайти собі роль, уявити собі, як діє людина, що вона говорить. Уява виявляється і розвивається також у пошуку засобів для виконання задуманого. Так у грі розвиваються творчі здібності школяра.

Найважливіша умова успішності дидактичної гри - уміння завоювати довіру учнів, установити 3 ними контакт. У висловленнях К. Ушинського, А. Макаренко гра розглядається як самостійна творча діяльність учнів. У педагогічних дослідженнях і в практиці шкіл думки А. Макаренко знаходять свій розвиток і підтвердження. Практика показала,що лише добре організована, чітко продумана гра здатна захопити учнів, виконати всі завдання, які стоять перед нею. Саме тому вчитель початкових класів повинен добре оволодіти методикою проведення дидактичних ігор, знати принципи їх побудови, особливості використання на тому чи іншому етапі уроку.

Кожна дидактична гра ефективна, коли їй передує підготовча робота. Вчитель повинен керуватись змістом програми і враховувати принципи побудови системи ігор: дидактичний, психологічний і моральний.

Дидактичний принцип вимагає опори на логіку самого предмета, програму і навчальний план. Більшість ігор призначені для поповнення, закріплення чи систематизації знань, одержаних в 
процесі навчання, тому вчителю потрібно враховувати: чи пройдено по програмі навчальний матеріал, який ступінь його засвоєння.

Психологічний принцип побудови системи дидактичних ігор передбачає, що при їх виборі потрібно враховувати вікові можливості та інтереси школярів. Прості ігри, як і дуже складні, не викликають в учнів інтересу, зацікавленості, тому гра за ступенем складності повинна відповідати рівню психічного розвитку дітей.

Відповідно до моральних принципів дидактичні ігри сприяють формуванню в дітей суспільних якостей. На уроках спочатку виконують ігри, в яких учні поодинці виконують завдання, а потім ігри, які допомагають виробити вміння включатися у дію для спільного розв'язання дидактичних завдань групою школярів. Водночас учитель повинен звертати увагу на виховання у школярів почуття відповідальності за свої дії перед усім колективом класу [9].

Готуючись до проведення дидактичних ігор та ігрових ситуацій, вчитель має продумати:

- вміння і навички, які необхідно сорормувати у дітей;

- виховні завдання, які необхідно реалізувати;

- матеріал, який краще використати для гри;

- як за мінімально короткий час ознайомити дітей з правилами гри;

- час проведення гри;

- організацію гри;

- зміну правил гри з метою активізації усіх школярів;

- підведення підсумків гри.

До відбору дидактичних ігор висуваються вимоги, які використовуватимуться у процесі навчання молодших школярів:

- цілеспрямованість використання;

- тривалість проведення;

- емоційність;

- близькість тематики до дитячого кругозору;

- різноманітність орорм організації учнів;

- підпорядкованість освітній роботі на уроці;

- нерозривний зв'язок дидактичної гри з іншими методами навчання.

До дидактичної гри потрібно готувати різноманітні ігрові атрибути або ігрове обладнання: букви, набірне полотно, карточки, набори картинок, іграшки, плоди, насіння, предмети домашнього вжитку, геометричні фрігури, дзвіночок, вимпел або прапорець для виділення колективного переможця, фрішки, двокольорові ракетки тощо. Частина матеріалу ігрового обладнання заготовлюється учнями, а також самим учителем. Пожвавлення у гру вносить пісочний годинник. Учні бачать, як зменшується кількість піску в ньому і тому намагаються вкластись у більш короткі строки, швидше виконати поставлене завдання.

Необхідно продумати фрорму організації учнів у процесі дидактичної гри при вивченні матема- тики, забезпечуючи активність кожного учасника. Дидактичні ігри частіше за все проводяться за столами, коли учні всі одночасно маніпулюють дрібними іграшками, карточками, викладають різні геометричні фрігури із однакової кількості паличок; розкладають монети різної вартості; групують предмети за певною ознакою; сигналізують свою відповідь кольоровими світлофорами, карточками з зображенням цисрр, букв, складів.

Дидактичні ігри побудовані 3 врахуванням потреби учнів у русі. Вони містять у собі завдання відшукати предмети; знайти і по секрету повідомити вчителю; визначати предмети навпомацки. Велика кількість дидактичних ігор вимагає від учнів при виконанні завдання діяти по черзі команди, або групами, а інші учні слідкують за правильністю їхніх дій тощо.

Важливим в організації дидактичних ігор $€$ вміння вибирати ведучого:

- за пропозицією вчителя. Він пропонує вибрати ведучим певного учня, коротко пояснюючи свій вибір. Цей спосіб зручний в тому разі, якщо для проведення гри мало часу;

- за результатами проведеної раніше гри. Ведучим стає той, хто виграв у попередній грі був самим кмітливим, уважним.

Кожний 3 описаних способів вибору ведучих для гри має свої переваги і недоліки, тому їх доцільно чергувати.

Способи попереднього розподілу гравців за командами.

1. За допомогою рахунку за номерами, залежно від кількості команд - перший-другий, або перший-другий-третій, за рядами тощо.

2. За вказівкою вчителя. Перевага цього способу в тому, що вчитель може сорормувати рівні за силами команди, що часто необхідно для ігор 3 елементами змагання.

3. Розподіл за вибором капітанів команд. Спочатку гравці вибирають капітанів, а потім капітани комплектують свої команди за домовленістю 3 ними.

4. Формування постійних команд. Це зручно для проведення ігор з елементами змагання.

У багатьох дидактичних іграх доводиться встановлювати право першого ходу. Отже, послідовне і систематичне навчання школярів різним способом організації дидактичних ігор дозволяє фрормувати самоорганізацію колективу школярів.

Учитель початкової школи повинен знати mexнологію проведення дидактичної гри на уроках математики в початкових класах:

I - етап - ознайомлення з грою. На цьому етапі вчитель активно проявляє керівну роль. Під час ознайомлення 3 новою грою дітям повідомляється її зміст, кількість учасників, їхня роль у грі, призначення ігрового матеріалу і способи його використання. 
II - етап - засвоєння гри в результаті їі багаторазового проведення. Як і на першому етапі, вчитель бере активну безпосередню участь, виконуючи роль ведучого, гравця, спостерігача.

III - етап - проведення гри з учнями. Учитель здійснює опосередковане керівництво грою, переважно через її правила.

IV - етап - школярі не тільки грають у гру самостійно, але й можуть змінювати, ускладнювати ії, навчити грати в неї своїх однолітків. Звичайно, самостійно грати у дидактичні ігри учні можуть лише тоді, коли вони добре засвоїли сюжетну лінію конкретної гри, свої ігрові дії в ній, можуть самостійно підготувати все необхідне для гри і почати її без допомоги дорослого.

Під час дидактичної гри учням необхідно дотримуватися правил:

- уважно слухати і запам'ятовувати необхідні дії, їх послідовність;

- не поспішати виконувати завдання, не дослухавши вчителя;

- уважно слухати відповідь учня, щоб у разі потреби щось виправити або доповнити;

- відповідати за викликом;

- дотримуватись своєї черги, бути дисциплінованим;

- чесно визнавати свої помилки;

- не хитрувати, не шукати нечесного шляху для перемоги.

Успіх гри багато в чому залежить від чіткого пояснення правил. Під час проведення дидактичних ігор на уроці керівна роль належить учителю. Початок гри потрібно проводити в дещо вповільненому темпі, щоб учні краще засвоїли правила. Якщо правила складні, то потрібно запропонувати пробний хід, а потім перейти до проведення самої гри. Чим чіткіше виконуються правила, тим інтенсивніше проходить гра.

Слушним $€$ те, що вчитель передає керівництво грою одному 3 школярів після того, як всі учні засвоять правила. На нашу думку, це привчає дітей що самостійності, вміння слухати товариша. Темп гри зростає під час розгортання дій. Учителю потрібно стежити за темпом гри, оскільки надто швидкий темп збуджує учнів чи може внести розгубленість, уповільнений - утомлює учасників гри.

Учителя повинен цікавити результат гри, який $є$ показником рівня засвоєння знань, вмінь, ступеня сорормованості навичок, здатності застосувати одержані знання на практиці. Результат гри показує, які встановились позитивні взаємовідношення у колективі.

Після закінчення гри вчитель підводить підсумки, визначає разом з учнями переможця, вказує на допущені помилки, виражає впевненість в тому, що учні, які потерпіли поразку, зможуть виграти наступного разу, якщо будуть більш уважними, кмітливими, спостережливими, сво- єчасно прийдуть на допомогу однокласникам. Велике значення має форма, у якій учитель оцінює результати змагання. В усіх випадках підбиття підсумку гри перша й основна форма оцінювання - похвала.

Система підбиття підсумків гри передбачає:

- доброзичливе ставлення до учня;

- позитивне оцінювання зусиль учня, спрямоване на розв'язання завдання в усіх випадках, навіть тоді, коли ці зусилля не приводять до позитивного результату;

- детальний аналіз утруднень учня і помилок, допущених ним;

- конкретні вказівки, спрямовані на поліпшення досягнутого результату.

Вчителю дуже важливо вміти створювати атмосфреру емоційного комфрорту в класі, невимушеності, в якій зливається воєдино навчання та гра - найефективніша фрорма пізнання нового, міцного засвоєння набутих знань з математики.

У педагогіці ігрова діяльність розглядається як потреба учня і як засіб педагогічного впливу. Будучи необхідною умовою фрізичного, психічного й інтелектуального розвитку молодших школярів, дидактична гра дозволяє цілеспрямовано розв'язувати завдання освітньої роботи у початковій школі.

Цілеспрямованість використання гри передбачає вміння вчителя орієнтуватися в дидактичних іграх [9].

Дидактичні ігри класифрікують:

- за наявністю чи відсутністю ігрового матеріалу;

- за ступенем складності ігрових дій, з врахуванням використання навчального матеріалу;

- за змістом дидактичної гри тощо.

Розрізняють дидактичні ігри 3 врахуванням навчального часу і ступеня складності ігрових дій:

- ігри-мініатюри 3-5 - хвилин;

- ігри-епізоди - 5- 10 хвилин;

- ігри-уроки.

Ігри-мініатюри зазвичай вимагають великого напруження уваги, швидкого орієнтування. Вони можуть проводитись у середині уроку, в кінці або на початку уроку.

Ігри-епізоди, у яких учням потрібно вміти порівнювати предмети і їх зображення, об'єднувати предмети за ознаками, краще проводити в кінці занять, коли учні стомляться від інших видів роботи. Окремі ігри-епізоди можуть тривати 15 хвилин і проводяться тільки в кінці уроку.

Ігри-уроки надають ігрової форми всьому уроку. Та педагогу слід пам'ятати, що дидактична гра вимагає від школярів значного напруження уваги, пам'яті. Тому при ії̈ проведенні вчитель повинен спостерігати за учнями і при появленні у них перших ознак втоми чи сильного збудження, закінчити гру чи змінити види роботи. 
За змістом дидактичні ігри діляться на ігри, що ознайомлюють $з$ оточуючим світом, розвитку мовлення, розвитку математичних уявлень, ігри музичні, образотворчі, оздоровчі тощо.

Отже, необхідне педагогічно доцільне поєднання ігрової діяльності та навчання. Дослідження показали, що гра, яка епізодично вводиться, не може здійснити суттєвий вплив на стійкість емоційно-позитивного відношення молодшого школяра до навчального процесу.

Тож необхідна організація ігрової діяльності у системі уроків. Це передбачає не тільки попередній вибір ігор та ігрових ситуацій для активізації різних видів сприймання, але і обдумане використання ігрового матеріалу з теми. Тому ефективність кожної гри буде залежати перш за все від того, наскільки своєчасно вона використана і якою мірою відповідає завданням уроку.

Вивчення педагогічного досвіду впровадження дидактичної гри на уроках математики дають змогу виділити основні способи використання гри у структурі уроку:

- урок будується як ігрова композиція з певної теми;

- під час уроку в розгорнутому плані використовується сюжетно-рольова гра або її елементи (на 5-6 хвилин);

- у процесі уроку створюються ігрові ситуації;

- в ігровій фрормі проводяться фрізкультхвилинка.

Самоорганізація, і довільність, добровільне підкорення правилам, і вміння керувати своїми бажаннями, і досвід співробітництва 3 іншими учнями - все, що з таким зусиллям дається у навчальній роботі, вже існує і розвинуте на рівні ігрової діяльності учнів. Те, що учневі дається 3 зусиллям у навчанні, у грі - не тільки доступне, але й бажане.

У вміло побудованій дидактичній грі учні систематизують і закріплюють математичні знання, засвоюють загальні поняття. Багато ігор допомагають повторити отримані знання у нових умовах, що сприяє більш глибокому засвоєнню матеріалу. Дидактична гра активізує пізнавальну діяльність молодших школярів, розвиває інтерес до навчання, спонукає шукати в одержаних знаннях відповіді на нові запитання, виникає інтерес до математики, повага до вчителя.

Якщо в учнів фрормуються пізнавальні інтереси, перебіг навчання завжди успішний. Школярі стають активнішими, що проявляється в численних запитаннях, у намаганні брати участь в різних видах діяльності, в обговоренні розглянутих на уроці питань, у доповненні відповідей товаришів, в активному оперуванні математичними знаннями і вміннями, у прагненні осягнути ще невідоме, глибше проникнути в предмет свого інтересу. Вибіркове спрямовування школяра до математич- них знань, видів діяльності, фрорм роботи допомагає йому краще зосередити свої зусилля, відчути більший успіх, задоволення. Використання дидактичної гри на уроках математики в початкових класах значно підвищує його ефективність. Продуктивність навчальної праці школярів різко зростає: вони виконують багато математичних вправ у швидкому темпі. Дидактична гра вселяє віру у свої сили, бажання досягнути позитивних результатів.

Поряд із навчальним реалізується і виховний ефект: зростає доброзичливість у стосунках, взаємодопомога співпереживання, поступово формується єдиний дружний колектив.

Отже, дидактична гра на уроках математики в початкових класах використовується:

- під час вивчення нового матеріалу;

- для активізації засвоєння матеріалу;

- для закріплення, поглиблення, повторення пройденого;

- для вироблення навичок і вмінь, фрормування автоматизму у застосуванні правил;

- для активізації уваги у процесі уроку;

- для зняття інтелектуального напруження, втоми викликаної розумовою працею;

- для діагностики результативності навчання, засвоєння програмних знань;

- для розвитку пізнавальної активності, підтримання інтересу до процесу оволодіння знаннями;

- для фрормування психічних якостей, які забезпечують успішність в оволодінні математичними знаннями;

- для внесення різноманітності у навчальну роботу;

- для розв'язання певних завдань виховної роботи, яка проводиться у процесі навчання.

За багатьох позитивних якостей дидактична гра в навчанні молодших школярів не може повністю витіснити строго регламентовану навчальну діяльність, оскільки навчання в дидактичній грі специфрічне: гра менш універсальна, ніж навчальне заняття; вона має менше можливостей для засвоєння нових знань; не весь програмний матеріал може засвоюватись через гру; полегшуючи процес навчання, гра не дає можливості тренувати школярів в тих психічних і фрізичних зусиллях, які необхідні для навчальної праці.

Дидактична гра на уроках математики у початкових класах використовується тоді, коли тільки вона може дати найкращі результати у засвоєнні учнями знань, вмінь і навичок. Для того, щоб дидактична гра була результативною, вчителю потрібно оволодіти технологією їх проведення.

Отже, розвитком творчого мислення на уроках математики необхідно керувати. Організація такої діяльності - створення умов для якісної освітньої роботи, які передбачають:

- Проводити навчання на високому рівні складності; 
- Посилити роль гіпотетичного мислення, що сприяє здібності передбачати, висловлювати свої думки, ідеї та захищати їх;

- Систематично створювати ситуації вибору для учнів і давати можливість здійснювати цей вибір;

Саме впровадження на уроці дидактичних ігор може сприяти розвитку пізнавальної активності у школярів. Використання дидактичних ігор дає змогу практично застосовувати математичні знання дітей. Для цього вчителям необхідно володіти сучасними методами, які б пробуджували у школярів бажання пізнавати нове, незвідане. Набір дидактичних розвиваючих ігор, вправ, може сприяти розвитку різноманітних якостей і здібностей у школярів, для допомоги у тому, щоб проявляти і реалізовувати пізнавальну активність у процесі розкриття і засвоєння шкільного матеріалу.

Математичні розвиваючі ігри, ребуси, логічні завдання дають можливість розвивати пізнавальні здібності, розвивати мислення, просторову уяву, франтазію, пам'ять, увагу учнів, допомагає учням оволодіти вмінням аналізувати, порівнювати, узагальнювати, проявляти кмітливість і винахідливість.

Висновки. Особливу роль серед активних методів навчання відіграють дидактичні ігри 3 математики. Під час використання ігрового методу на уроках у початкових класах варто керуватися правилами:

- ігрове завдання завжди має збігатися зі змістом навчального завдання;

- частка ігрового методу навчання повинна знижуватися відповідно до формування пізнавальних інтересів учнів;
- дидактична гра повинна мати чітко визначену дидактичну мету, яка повинна бути підпорядкована цілям кожного конкретного уроку і допомогти досягненню цих цілей;

- дидактична гра має відповідати віковим особливостям учнів;

- дидактична гра проводиться систематично і цілеспрямовано протягом навчального року.

Питання використання дидактичних ігор у початкових класах важливе й актуальне. Ми продовжимо його вивчати в процесі безпосередньої роботи в школі, узагальнивши прогресивний педагогічний досвід вчителів із використання дидактичної гри в освітньому процесі молодших школярів.

\section{БІБЛІОГРАФІЧНИЙ СПИСОК:}

1. Дичківська І. Інноваційні педагогічні технології. Київ : Академвидав, 2012. 352 с.

2. Комар О. Інтерактивні методи навчання в сучасній дидактиці. URL: http://dspace.udpu.org.ua:8080/ jspui/handle/6789/374.

3. Макрідіна Л. Сучасні технології навчання: Рідна школа. 2002. С. 46-49.

4. Освітні технології / за ред. О. Пєхота. Київ : A.C.K., 2004. 225 c.

5. Пащенко М. Інноваційні педагогічні технології : навч. посіб. Умань : ПП Жовтий О.О., 2016. 269 с.

6. Освітні технології / за ред. О. Пєхота. Київ : A.C.K., 2004. 225 c.

7. Слєпкань 3. Формування творчої особистості учня в процесі навчання математики. Математика в школі. 2003. № 1, 3.

8. Степанов О., Фібула М. Основи психології і педагогіки : посібник. Київ : Академвидав, 2003. 504 с.

9. Янківська О. Дидактичні ігри. Київ : Радянська школа, 1985. 144 с. 